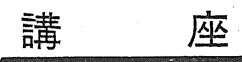

入門講座・エマルション

\title{
$\mathrm{W} / \mathrm{O} / \mathrm{W}$ 型エマルション状態について
}

\author{
松本幸雄 \\ 大阪府立大学農学部農芸化学科（堺市百舌鳥梅町）
}

\section{On the State of W/O/W Emulsions}

Sachio Matsumoto

Department of Agricultural Chemistry, College of Agriculture, the University of Osaka Prefecture (Mozu-umemachi, Sakai, Osaka)

\section{1 はじめに}

1925 年, ドイツの生化学者 Seifriz ルションが転相する過程で, 分散相の内部にさらに分散 粒子が存在する状態があらわれる場合があることを指摘 し，このような状態にある系を多相エマルション（複合 エマルションあるいは多重エマルションとも称される) と名付けた。このことは, Becher ${ }^{2)}$ や Sherman ${ }^{32}$ の成 書に触れられている。エマルションの転相の際に多相型 が生成する事実は, 現在の視点 ${ }^{4}$ からすれば, 乳化剤の 親水性と親油性とのつり合い(HLB) の変化と関連した 現象であることを示唆する重要な発見であると考えられ るが，実際に多相エマルション状態が人々の注意をひく ようになったのは，それから 40 年を経た 1965 年以降 のことである。この年, 抗原抗体反応の研究において抗 原を生体に与える際, その凨形として W/O/W 型の多相 エマルションを使用することの有用性が Herbert ${ }^{5)}$ によ って示された。続いて Engel ら゚は, インシュリンを W/O/W 型エマルションを用いてカプセル化し，これを 実験動物に経口投与したところ, 血糖值の低下に有効で あったと報告している。以後, 製剂学の分野でドラッグ デリバリーシステムとして, あるいは液膜分離操作にお ける液膜のベースとして，いずれも実用的な立場から多 相エマルション状態が注目されるようになったのであ る $^{7,8)}$ 。

しかし，これらの実際的応用を目的とする研究の内容 を追跡しても, 多相エマルションの生成機構や生成系の 状態についての基本的な概念を把握することは, 研究内 容の多樣性の故にいささか困難である。筆者 ${ }^{92111}$ は, 種 々のマクロエマルション状態を非平衡系のモデルとして 観察の対象にしてきたいきさつから，多相エマルション についてもその具体的な応用から少し距離をおいて生成

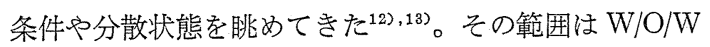

型に限られ，未知の部分も多いが，本稿ではこれまでに 得られた知見について述べ，本講座の一端とさせていた だきたい。

\section{2 多相エマルション状態}

実在するエマルション状態は，よく知られているよう に O/W 型と W/O 型とに分類される。乳化操作におけ る乳化剤の選択 ${ }^{14)}$ と, 生成したエマルションの性質や用 途は，分散媒が水であるか油であるかによっていちじる しく異なるから，この分類は基礎的及び実用的に重要な 意味をもつ。多相エマルションもこの分類の範ちゅうに あり，分散媒が水相である状態を W/O/W 型，油相から なるものを $\mathrm{O} / \mathrm{W} / \mathrm{O}$ 型と称し, 前者が $\mathrm{O} / \mathrm{W}$ 型の多相状 態, 後者が W/O 型のそれであると理解することができ る。すなわち, W/O/W 型エマルションは水中（外水相 中）に分散した油滴中にさらに水（内水相）が分散した 状態のものであり，O/W/O 型エマルションはその逆の 状態のエマルションである。ただし，分散媒と内水相 （もしくは内油相）とを成分的に区別することがあるの で, この場合 $\mathrm{W}_{2} / \mathrm{O} / \mathrm{W}_{1}$ 型, あるいは $\mathrm{O}_{2} / \mathrm{W} / \mathrm{O}_{1}$ 型と記 される。例えば, W/O/W 型の内水相に特定水溶性成 分を添加したり, $\mathrm{O} / \mathrm{W} / \mathrm{O}$ 型の分散媒と内油相に異種 の油を用いる場合がこれに 相当する。

多相エマルションの分散 相濃度は, 内水相 $(\mathrm{W} / \mathrm{O} / \mathrm{W}$ 型) もしくは内油相 $(\mathrm{O} / \mathrm{W} /$ O型) と，これを取り囲む 油相 (W/O/W 型) もしく は水相 $(\mathrm{O} / \mathrm{W} / \mathrm{O}$ 型) の量 の和である。簡単のため,

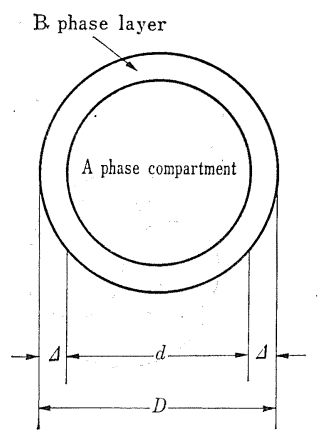

図-1 最も単純な多相エマル ション分散粒子の形態 模式図 ${ }^{18)}$ 
図-1 に模式的に示すように, 直径 $d$ なる一個の内相 (A相とする) の周囲に厚さ $\Delta$ の別の相 (B相とする) が分配されて, 直径 $D(=d+2 \Delta)$ の分散粒子が形成さ れた状態を考えてみよう。このような系の分散相体積分 率 $\phi$ は，A相の体積分率 $\phi_{A}$ とB相のそれ $\phi_{B}$ との和 であるから，

$$
\phi=\phi_{A}+\phi_{B}=\pi n D^{3} / 6=\pi n(d+2 \Delta)^{3} / 6
$$

ここに, $n$ は単位体積試料中に存在する分散粒子の個数 である。さらに, 多相エマルションでは, 分散粒子中で 占めるA相の体積分率 $\phi_{A} / \phi$ が, 分散粒子の形態上ある いは実用上重要である。すなわち, 式 (1) から

$$
\phi_{A} / \phi=d^{3} / D^{3}=d^{3} /(d+2 \Delta)^{3}=(D-2 \Delta)^{3} / D^{3}
$$

したがって，A相を取り囲む $\mathrm{B}$ 相の厚さ $\Delta$ は

$$
\Delta=\left[\left(\phi / \phi_{A}\right)^{1 / 3}-1\right] d / 2=\left[1-\left(\phi / \phi_{A}\right)^{1 / 3}\right] D / 2
$$

分散粒子を構成する $\mathrm{A}$ 相の体積分率 $\phi_{A} / \phi$ と $\mathrm{B}$ 相の厚さ $\Delta$ との関係を, 式 (3) を用いて計算してみると図-2 の ようである ${ }^{13)}$ 。例えば，分散粒子体積の半分が $\mathrm{A}$ 相であ る $\left(\phi_{A} / \phi=0.5\right)$ 場合, $\Delta$ の值は分散粒子直径 $D$ が 1 $\mu \mathrm{m}$ のとき約 $0.1 \mu \mathrm{m}$ であり, $\mathrm{A}$ 相体積が分散粒子の $1 / 5\left(\phi_{A} / \phi=0.2\right)$ の場合でも $\Delta$ は約 $0.2 \mu \mathrm{m}$ となり, 光学顕微鏡観察の対象たり得ないことがわかる。このよ

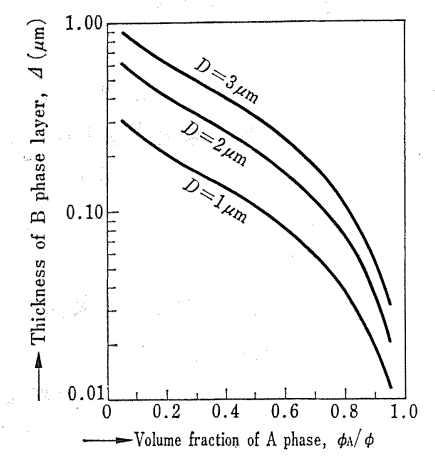

图-2 多相エマルション分散粒子中の $\mathrm{A}$ 相の体積分率と $\mathrm{B}$ 相の厚さの関倸 $(\text { 図-1 参照 })^{13)}$

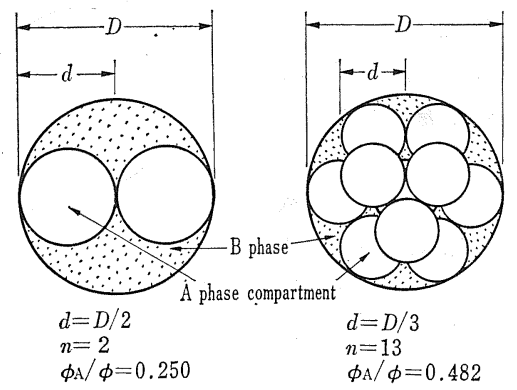

图-3 複数個の $\mathrm{A}$ 相からなる多相エマルション分散粒子 一個の形態模式図 ${ }^{13)}$
うに，多相エマルションの分散粒子は，薄い液体膜から なる小胞体構造をもつと考えられる。特に, W/O/W 型 エマルションでは, 後述するように水粒子を取り囲む油 膜に薄膜化が起こるので, 水粒子は油相量に無関係にき わめて薄い油膜に覆われて 分散している ${ }^{122}$ 。なお，一 個の分散粒子中に二個以上の $\mathrm{A}$ 相粒子が存在するとき, 図-3 に模式的に示すようにその数が増すとともに $\phi_{A} / \phi$ も当然増すが, 実際には二個以上の $\mathrm{A}$ 相粒子は $\mathrm{B}$ 相内で 互いに接触し, 多面体として存在する様子が検鏡され る。このとき，接触面を形成する $\mathrm{B}$ 相の平面膜むきわめ て薄い。

\section{$3 \mathrm{~W} / \mathbf{0} / \mathrm{W}$ 型エマルションの生成}

$\mathrm{W} / \mathrm{O} / \mathrm{W}$ 型 エマルションを生成させるために必要な条 件は, 乳化㓮の選択と組み合わせが W/O 型エマルショ ンの調製が可能な程に低い HLB 範囲にあること, 及び 乳化剂の踈水基（炭化水素鎖）が試料を調製する温度領 域で融解していること，の二点に集約されるようであっ て, 調製操作そのものはそれ程重要ではないと思われ る。

$30 \%$ の Span 80 (ソルビタンモノオレエート) を含 む流動パラフィンを $0.5 \%$ Tween 80 (ポリオキシエチ レンソルビタンモノオレエート) 水溶液と混合し, 機械 的にかきまぜて生成した $\mathrm{O} / \mathrm{W}$ 型エマルションについて 液相遠心沈降法 ${ }^{15}$ により粒子分析を行うと, 図-4に示 すように粒度分布に二つのピークがあらわれるが，同じ 生成試料の分散媒部分に $0.5 \%$ から $1 \%$ 濃度になるよ うにブドウ糖を添加してから再度粒子分析を行うと，大 きい粒径領域の分布は消滅する ${ }^{16)}$ 。あるいは, 同様にし て調製した $\mathrm{O} / \mathrm{W}$ 型エマルションの見掛けの粘度は, 図一 5 に示すように油相中の Span 80 濃度の増加とともに

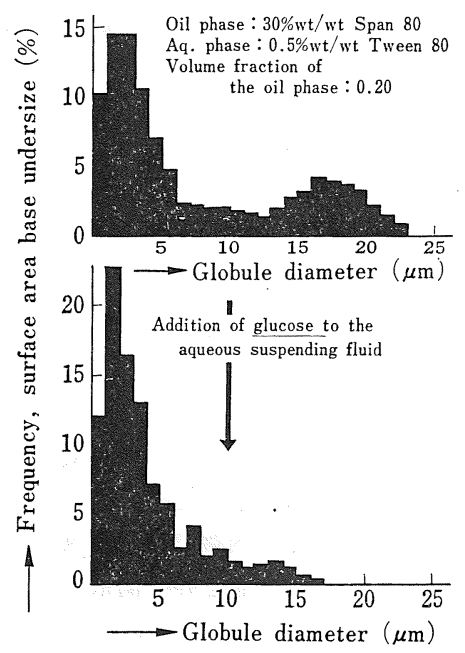

図-4 単純なかきまぜによる W/O/W 型エマルションの 生成とブドゥ糖の添加によるその消滅 ${ }^{16)}$ 


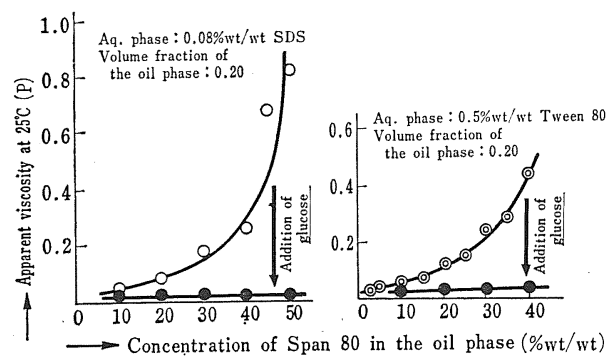

図-5 W/O/W 型分散の生成にともなう $\mathrm{O} / \mathrm{W}$ 型 エマルションの高粘性現象 ${ }^{16)}$

急激に増すが，試料調製の際のかきまぜ終了直前に系に 少量のブドウ糖を添加すると, 生成した $\mathrm{O} / \mathrm{W}$ 型エマル ションの粘度は油相中の Span 80 濃度に無関係に, お よそ一定の值をとるようになる ${ }^{16)}$ 。これらの結果から， 単純なかきまぜによって $\mathrm{O} / \mathrm{W}$ 型エマルションを調製す る際に W/O/W 型分散が生成する場合があることは明ら かであり，ブドウ糖添加による粗大粒子の消失や系粘度 の低下は，油滴中に取りこまれた水（内水相）が分散媒 との浸透圧勾配により分散媒部分へ移行することを示唆 する。なお，W/O/W 型分散の生成にともなう $\mathrm{O} / \mathrm{W}$ 型 エマルション粘度の増加は，分散相である油相の濃度に 内水相の量が加わるのがその要因であることはいうまで もない。これを Mooney 型の粘度式 ${ }^{17) て ゙ あ ら わ す と ， ~}$ 次のようである ${ }^{18), 199}$ 。

$$
\ln \eta_{\mathrm{re} 1}=a\left(\phi_{0}+\phi_{\mathrm{W}}\right) /\left[1-k\left(\phi_{0}+\phi_{\mathrm{W}}\right)\right]
$$

ここに, $\eta_{\mathrm{rel}}$ は試料相対粘度, $\phi_{0}$ と $\phi_{\mathrm{W}}$ は油相及び内 水相の体積分率， $a$ と $k$ は定数である。

単純なかきまぜで $\mathrm{W} / \mathrm{O} / \mathrm{W}$ 型エマルションが生成する 乳化剂量は，使用する乳化剤の種類とその組み合わせに よって特異的であるが，0.15M SDS（硫酸ナトリウム ドデシル) 水溶液に対する油相中の Span 80 濃度の関係 については，図-6 に示すような $\mathrm{W} / \mathrm{O} / \mathrm{W}$ 型分散生成領 域が観察される ${ }^{20)}$ 。ちなみに, 図-6 の縦軸には, W/O/ $\mathrm{W}$ 型エマルション生成率の指標として 単位体積試料中 で小胞体を構築する油膜の面積を示した ${ }^{12), 13) 。 ~}$

人為的に $\mathrm{W} / \mathrm{O} / \mathrm{W}$ 型エマルションを調製しようとする とき，特に前述の $\mathrm{W}_{2} / \mathrm{O} / \mathrm{W}_{1}$ 型の系が必要な場合には， いわゆる二段階乳化法 ${ }^{21) ~ 23)}$ が有用である。すなわち， 親油性乳化剤を用いて W/O 型エマルションを調製し， これを親水性乳化剂水溶液中へ分散させる方法である。 この場合, $\mathrm{W} / \mathrm{O} / \mathrm{W}$ 型エマルションの生成率は, あらか じめ内水相に添加したマーカーが試料調製後外水相へ移 行している量から 評価することができる ${ }^{21}$ 。図-7 は, このようにして求めた二段階乳化における W/O/W 型分 散生成率と，一連の親水性乳化剂に対する Span 80 の 重量比との関係を示したもので, 例えば Span 80 と Tween 20 (ポリオキシエチレンソルビタンモ)ラウレ

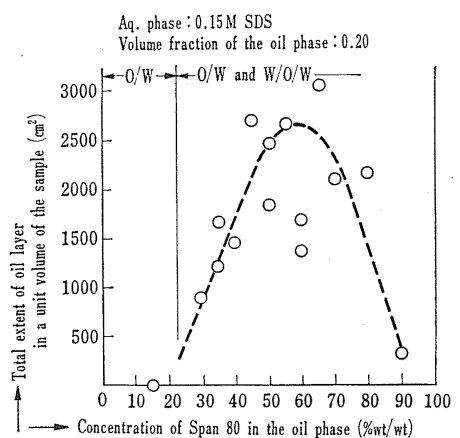

図-6＼cjkstart単純なかきまぜによる $\mathrm{W} / \mathrm{O} / \mathrm{W}$ 型 エマルション生成領域 ${ }^{20)}$

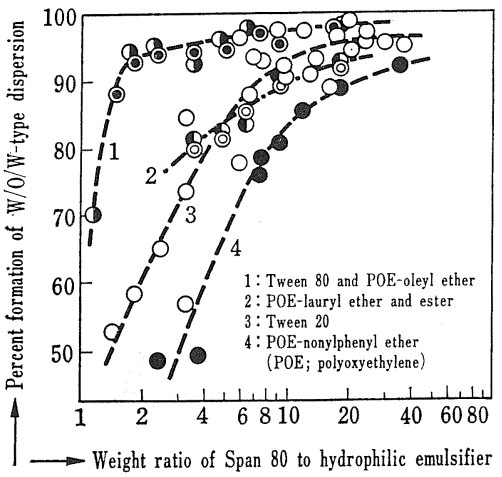

図-7 二段階乳化法における W/O/W 型分散生成率と 使用した親油性親水性両乳化剈の量比との関係 ${ }^{21}$

ート）との組み合わせでは，前者を後者の 10 倍量以上 使用した系で $90 \%$ 以上の $\mathrm{W} / \mathrm{O} / \mathrm{W}$ 型分散生成率が得ら れることがわかる。

Seifriz ${ }^{1)}$ が発見したマクロエマルション転相時の多相 系生成現象を再現させるため，筆者 ${ }^{24)}$ は Span 80 を含 む流動パラフィンに, SDS, CTABr (ヘキサデシルトリ メチルアンモニウム=ブロミド)，あるいは Tween 80 の水溶液を少量ずつ添加しながらかきまぜを続ける操作 を試みた。その結果，この操作の初期には例外なくW/ O 型エマルションが生成するが，親水性乳化剤水溶液の 添加量がある量に達すると系は突然 $\mathrm{O} / \mathrm{W}$ 型に転相し; このとき $\mathrm{W} / \mathrm{O} / \mathrm{W}$ 型エマルションが $\mathrm{O} / \mathrm{W}$ 型に混在して あらわれる場合があることが確認された。生成率の指標 に単位体積試料中の油膜面積を測定し，これを混合系に 含まれる親水性, 親油性両乳化㓮のモル比に対してプロ ットした結果は図-8に示す通りである。W/O/W 型エマ ルションの生成範囲は乳化剤の種類によって異なるが, これを一般化すれば，多相エマルションは O/W 型と W/O 型の中閒状態のものと考えることができる。前述 の単純なかきまぜによる $\mathrm{W} / \mathrm{O} / \mathrm{W}$ 型エマルションの生成 現象と合わせて, 多相エマルションはあらゆる乳化操作 において生成する可能性のある状態であるう。 


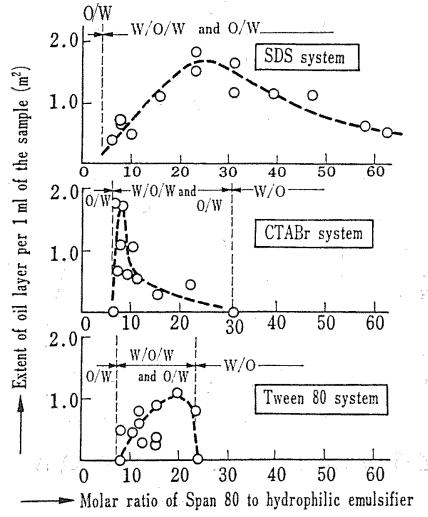

図-8 転相における W/O/W 型分散の生成領域 ${ }^{24)}$

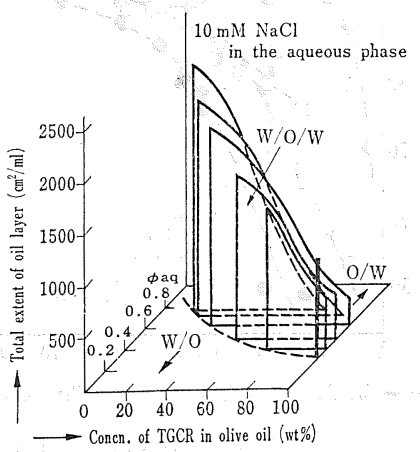

図-9 転相におけるオリブ油系 W/O/W 型エマルション 生成領域 $\left(\phi_{\mathrm{aq}}: \text { 添加水相の体積分率 }\right)^{25)}$

最近，筆者ら ${ }^{25)}$ はオリブ油にポリグリセリン脂肪酸エ ステル (食品用乳化剈) の一種であるテトラグリセリル 縮合リシノレート（以後 TGCR と略記）を溶解させ, これに水を添加しながらかきまぜを続けるだけで W/O 型エマルションから O/W 型への転相が起こり,このと きに W/O/W 型分散が生成する現象を見いだした。転相 に要する水の添加量は, オリブ油中の TGCR 濃度によ ってほぼ一義的に決まるので，この関係に W/O/W 型分 散の生成率を加えて W/O/W型 エマルション状態が存在 する領域を三次元的に表したのが 図-9 である。一種類 の親油性乳化剤の使用によって W/O/W 型エマルション が生成する機構については，今後の検討課題である。

\section{$4 \mathrm{~W} / \mathrm{O} / \mathrm{W}$ 型エマルション油膜の性質}

多相エマルションの分散粒子内部で占めるA相の体積 が少し増すと, A相を取り囲むB相が幾何学的に薄膜状 になることはすでに述べた通りであるが,実際にW/O/W 型エマルションの分散粒子を検鏡すると，定常状態にお いて内水相表面の油膜は使用した油相量に無関係にきわ めて薄い状態のものであることがわかる。水中で油膜に 包まれた水粒子をつくり，これを検鏡してみると，水粒
子形成直後から油膜に薄膜化が起こり，50 $\mathrm{s}$ 以内に水粒 子表面の油膜の $90 \%$ 以上が黒膜の状態にまで薄膜化し て定常状態にいたる状況が観察されるので ${ }^{12)}$ ，実際の系 でも小胞体を構築する油膜に同様の薄膜化が起こるので あろう。油膜の両面に加わる静水圧に続いてファンデル ワールス分離圧が作用して薄膜化が進行し, やがて油膜 両面の乳化剤吸着層内部における疎水基同士のエントロ ピー的斥力とつり合ったところで定常状熊にいたると考 えられる。なお，剩余の油相成分は油膜表面に局在し， あるいは油滴となって外水相中に分散する。油膜の薄膜 化は，W/O/W 型エマルションの生成条件には無関係に あらわれる。

薄膜化した油膜には，水を透過させる性質がある。例 えば，内水相と外水相に等濃度のブドウ糖が溶解する試 料をつくり，これを純水で希釈すると外水相中のブドウ 糖が希釈される結果，油膜を介して内水相との閒に濃度 勾配が生じ，外水相の水の一部は油膜を通って内水相に 移動するので，各小胞体は 図-10 に示すように膨潤す る ${ }^{26)}$ 。逆に, 高濃度のブドウ糖水溶液で希釈すれば，水 は内水相から外水相へ移動し，小胞体は収縮する ${ }^{199}$ 。 図-10のような結果を用いて，ブドウ糖濃度勾配 $\Delta g c(g$ はブドウ糖水溶液の浸透圧係数）における個々の小胞体 の膨潤速度 $\mathrm{d} v / \mathrm{d} t$ を求めると, 次式により油膜の水透 過係数 $P_{0}$ を計算することができる。

$$
\mathrm{d} v / \mathrm{d} t=P_{0} A \Delta g c \cdot \bar{V}
$$

ここに, $A$ は油膜面積, $\bar{V}$ は水の部分分子容である。こ のようにして得られた $\mathrm{W} / \mathrm{O} / \mathrm{W}$ 型エマルション油膜の水 透過係数は，その数例を 表-1 に示すように $10^{-4} \mathrm{~cm} / \mathrm{s}$ のオーダーであり，この值はリポソームのような脂質二 分子膜のそれに近い27)。したがって，薄膜化した油膜は 親油性乳化剤の二分子膜を基本構造とする膜であると考 えられる。

油膜状態の持続性は，W/O/W 型エマルション状態を 特徵づける油の小胞体の安定性の問題に直接かかわるの で28)，この種のエマルションを取り扱う上で重要な問題

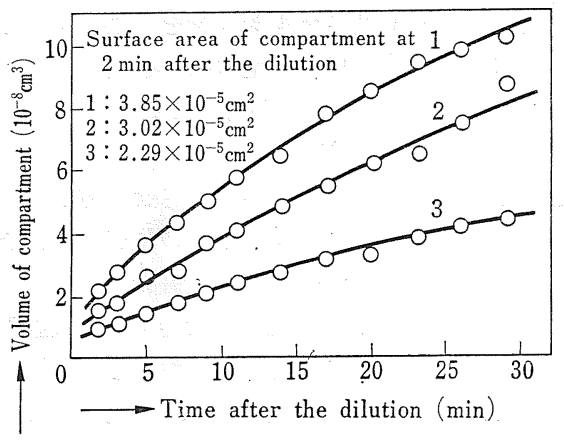

図-10 浸透圧勾配下での W/O/W 型エマルション 分散粒子の膨潤26) 
表-1 炭化水素采 $\mathrm{W} / \mathrm{O} / \mathrm{W}$ 型エマルション 油膜の水透過係数 ${ }^{26)}$ [式 (5) 参照]

\begin{tabular}{l|c|c|c}
\hline Hydrocarbon & $\begin{array}{c}A \\
\left(10^{-5} \mathrm{~cm}^{2}\right)\end{array}$ & $\begin{array}{c}\mathrm{d} v / \mathrm{d} t \\
\left(10^{-10} \mathrm{~cm}^{3} \cdot \mathrm{s}^{-1}\right)\end{array}$ & $\begin{array}{c}P_{0} \\
\left(10^{-4} \mathrm{~cm} \cdot \mathrm{s}^{-1}\right)\end{array}$ \\
\hline \multirow{3}{*}{$n$-Heptane } & 5.54 & 1.29 & 7.73 \\
& 4.78 & 1.21 & 8.40 \\
& 2.38 & 0.59 & 8.27 \\
& 2.83 & 0.54 & 6.35 \\
& 1.81 & 0.33 & 6.01 \\
& 1.08 & 0.20 & 6.18 \\
& & & av. 6.18 \\
\hline \multirow{3}{*}{ Kerosene } & 3.96 & 0.61 & 5.10 \\
& 2.46 & 0.39 & 5.23 \\
& 1.96 & 0.33 & 5.55 \\
& & & av. 5.29 \\
\hline \multirow{3}{*}{ Liquid paraffin } & 3.85 & 0.71 & 6.13 \\
& 3.02 & 0.43 & 4.78 \\
& 2.29 & 0.28 & 4.11 \\
& & & av. 5.01 \\
\hline
\end{tabular}

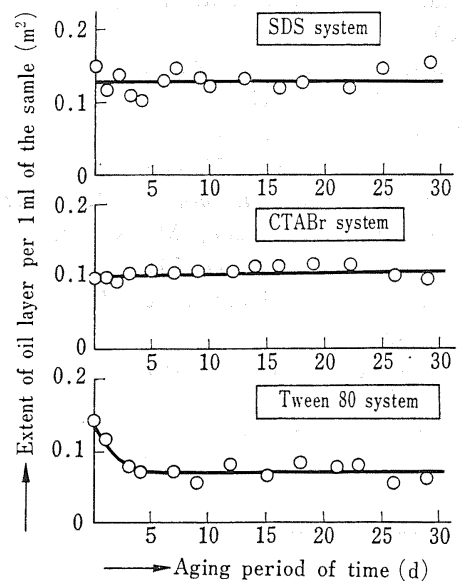

図-11 W/O/W 型エマルションの油膜の持続性 (図-8の各試料の場合) ${ }^{24)}$

の一つである。筆者ら 242,28$)$ が, 単位体積試料中の油膜 面積を試料を熟成させながら追跡した結果，図-11 にそ の一例を示すように，油膜状態の持続性は概して良好で あることがわかる。しかし，内水相や外水相に塩類や有 機酸類のような電解質が存在すると, W/O/W 型エマル ションの油膜面積は試料生成直後から減少しはじめ，小 胞体が早晚消滅する場合が多い29)。筆者ら ${ }^{30)}$ は, W/O/W 型エマルションの油相に脂肪酸や脂肪族アミンを添加し て油膜に荷電を付与することを試み，あるいは内外両水 相にタンパク質のような水溶性高分子を添加してその保 護コロイドとしての効果を期待したが，いずれも油膜面 積の減少速度を低下させる効果は認められても，まだ安 定化効果を得るにはいたっていない。むしろ，転相によ
り $\mathrm{W} / \mathrm{O} / \mathrm{W}$ 型エマルショ ンが自発する現象に対す る電解質類の影響を個々 に調べ，高い $\mathrm{W} / \mathrm{O} / \mathrm{W}$ 型 分散の生成率が得られる ような乳化剤の種類と組 み合わせ，及び濃度を検 索することにより, 安定 な油膜状態が得られる可 能性がある ${ }^{30)}$ 。これに対 し先に述べた TGCR を 用いて転相により得られ るオリブ油系 $\mathrm{W} / \mathrm{O} / \mathrm{W}$ 型 エマルションの油膜は,

図-12 に示すように食塩

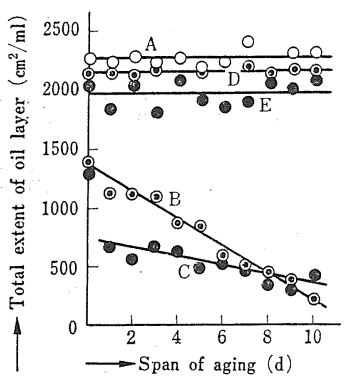

$\mathrm{A}$ ：食塩，B：ブドウ糖，C：酶酸，

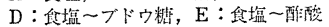

図-12 TGCR で調製したオリ ブ油系 $\mathrm{W} / \mathrm{O} / \mathrm{W}$ 型エマ ルションの油膜の持続性 に対する水相中の溶質の 影響25)
の存在により安定化する ${ }^{25)}$ 。この系のブドウ糖や酢酸存 在下で見られる油膜の不安定化も, 食塩を共存させるこ とにより著しく改善される結果は非常に興味深いが, そ の機構については不明である。

なお，これまで $\mathrm{W} / \mathrm{O} / \mathrm{W}$ 型エマルションの生成率や油 膜状態の持続性データーに用いてきた単位体積試料中の 油膜面積を評価する方法は，次の通りである ${ }^{13), 28) 。 ま ~}$ ず内外水相がブドウ糖により等張にある試料を純水で希 䣋し, 直ちに希橎系の粘度増加を可及的に精確に追跡す る。希釈による粘度増加は, 水の移動にもとゔく小胞体 体積の増加に由来したものであるから，希釈後の各時閒 における内水相体積分率 $\phi_{\mathrm{w}}$ の值は前出式 (4) を変形 した次の関係を用いて見積もることができる。

$$
\phi_{\mathrm{W}}=\left[\left(1-k \phi_{0}\right) \ln \eta_{\mathrm{re} 1}-a \phi_{0}\right] /\left(a+k \ln \eta_{\mathrm{re} 1}\right)
$$

上式の定数については, 実験的に $a=2.5, k=1.5$ の值 がそれぞれ得られているので ${ }^{18)}$ (19)，これらを代入すれ ばよい。したがって，単位体積試料における内水相体積 の増加速度 $\mathrm{d} \phi \mathrm{w} / \mathrm{d} t$ は, 希釈後の各時間において粘度か ら求めた $\phi_{\mathrm{W}}$ の増加曲線の勾配から推定できるので, 前出式 (5) の関係から次の計算の実施が可能になる。

$$
\mathrm{d} \phi_{\mathrm{w}} / \mathrm{d} t=P_{0} \bar{A} \Delta g c \bar{V}
$$

あるいは

$$
\bar{A}=\left(\mathrm{d} \phi_{\mathrm{w}} / \mathrm{d} t\right) / P_{0} \Delta g c \bar{V}
$$

ここに, $\bar{A}$ は求めようとする 単位体積試料中の油膜面 積である。なお, 油膜の水透過係数 $P_{0}$ の值は, 筆者 $ら^{26)}$ の実測では $(5 \pm 3) \times 10^{-4} \mathrm{~cm} / \mathrm{s}$ の範囲にあるが，光 学顕微鏡を用いて対象試料の透過係数を確認しておくこ とは必要であろう。

W/O/W 型エマルションの油膜状態は, 乳化剤の水相 と油相からの分離によってもたらされる相状態の一つに 相当すると考えられるから，これら多成分系の相図の中 で非平衡系である $\mathrm{W} / \mathrm{O} / \mathrm{W}$ 型分散の位置を確認したい。 
併せて, Friberg ら ${ }^{31)}$ の液晶相によるエマルション安定 化機構，及び鈴木ら ${ }^{22}$ の $\mathrm{O} / \mathrm{W}$ 型エマルションに打ける 二次粒子生成機構等の考え方に注目したい。

\section{5 おわりに}

本文中でむ触れたように，多相エマルションは決して 特別につくられた状態のエマルションではない。これま でに，いろいろな分野で $\mathrm{O} / \mathrm{W}$ 型及び W/O 型エマルシ ヨンが利用されてきたように，多相エマルションもやが て実際的応用の場が見いだされ，その状態が広く利用さ れるようになるであらう。そのためにも，これまでのエ マルション研究の流れの中で, 多相型分散の基本的な部 分にかかわる理解が一層展開することを期待したい。ま た，多相型分散の存在を考えることにより，エマルショ ン状態の複雑な物性の解析が容易になることをも期待し ている。読者各位の御批判をお願いする次第である。 (昭和 61 年 6 月 9 日受理)

\section{文献}

1) W. Seifriz, J. Phys. Chem., 29, 738 (1925)

2) P. Becher, "Emulsions, Theory and Practice", Reiro hold, New York (1965), p. 149

3) P. Sherman, "Emulsion Science", Academic Press, New York (1968), p. 206

4) 篠田耕三, 西條宏之, 油化学, 35, 308 (1986)

5) W.J. Herbert, Lancet, 2, 771 (1965)

6) R.H. Engel, S.J. Riggi, M.J. Fahrenbach, Nature, 219, 856 (1968)

7) S.S. Davis, Chem. Ind. (London), 1981, 683

8) A.T. Florence, D. Whitehill, Intern. J. Pharm., 11, 277 (1982)

9）松本幸雄, 表面, 20，80 (1982)

10）松本幸雄, 農化誌, 57, 333 (1983)

11）松本幸雄, 化学と生物, 23，653 (1985)
12) S. Matsumoto, in "Macro-and Microemulsions" (D.O. Shah, ed.), ASC Symposium Series, No. 272 (1985), p. 415

13) S. Matsumoto, in "Nonionic Surfactants, Physical Chemistry" (M.J. Schick, ed.), Marcel Dekker, New York, in Press

14) K. Shinoda, T. Yoneyama, H. Tsutsumi, J. Disp. Sci. Technol., 1, 1 (1980)

15) S. Matsumoto, S. Fukushima, J. Texture Stud., 5, 29 (1974)

16）松本幸雄, 牧野 博, 上野朝子, AOCS-JOCS ジョイン トミーティング講演, 1986 年 5 月

17) M. Mooney, J. Colloid Sci., 6, 162 (1951)

18) Y. Kita, S. Matsumoto, D. Yonezawa, J. Colloid Interface Sci., 62, 87 (1977)

19) S. Matsumoto, M. Kohda, J. Colloid Interface Sci., 73, 13 (1980)

20）牧野 博, 大阪府立大学修士論文, 1986

21) S. Matsumoto, Y. Kita, D. Yonezawa, J. Colloid Interface Sci., 57, 353 (1976)

22) S. Matsumoto, M. Kohda, S. Murata, J. Colloid Interface Sci., 62, 149 (1977)

23) S. Matsumoto, Y. Ueda, Y. Kita, D. Yonezawa, Agri. Biol. Chem., 42, 739 (1978)

24) S. Matsumoto, J. Colloid Interface Sci., 94, 362 (1983)

25) S. Matsumoto, Y. Koh, A. Michiura, J. Disp. Sci. Technol., 6, 507 (1985)

26) S. Matsumoto, T. Inoue, M. Kohda, K. Ikura, $J$. Colloid Interface Sci., 77, 555 (1980)

27) R. Fettiplace, Biochim. Biophys. Acta, 513, 1 (1978)

28) S. Matsumoto, T. Inoue, M. Kohda, T. Ohta, $J$. Colloid Interface Sci., 71, 564 (1980)

29) S. Matsumoto, P. Sherman, J. Texture Stud., 12, 243 (1981)

30）松本幸雄, 北山哲史, 高 裕明, 油化学 (英文), 34, 688 (1985)

31) S.E. Friberg, C. Solans, Langmuir, 2, 121 (1986)

32）鈴木敏幸, 油化学, 35, 113 (1986) 